\title{
Determinants of Environmental Disclosure in Thai Corporate Annual Reports
}

\author{
Muttanachai Suttipun (Corresponding author) \\ Prince of Songkla University, Thailand \\ Tel: +6674287868,e-mail: c3080496@uon.edu.au,muttanachai.s@psu.ac.th \\ Patricia Stanton \\ Newcastle Business School, Faculty of Business and Law \\ University of Newcastle, Australia \\ e-mail: Patricia.Stanton@newcastle.edu.au
}

Received: January 30, 2012 Accepted: March 08, 2012 DOI: 10.5296/ijafr.v2i1.1458

\begin{abstract}
This study investigated the extent and content of environmental information disclosure provided in the annual reports of companies listed on the Stock Exchange of Thailand (SET), and tested whether there were any relationships between the amount of environmental disclosure and a number of company characteristics used in previous studies conducted in more developed countries. By using a simple sampling method, 75 listed companies were selected for inclusion in the study based on their 2007 annual reports. The findings indicate that 62 companies (83\%) provided environmental information in their annual reports. Companies in the resources industry group made the most disclosure of environmental information, while the least disclosure was made by companies in the agricultural and food industries group. The most common location of environmental reporting in annual reports was under the topic of corporate governance. The most common themes of disclosures were environmental policy, environmental activities, and waste management. There was a positive relationship between the amount of environmental disclosures and size of company.
\end{abstract}

Keywords: Environmental disclosure, Annual reports, Thailand, The Stock Exchange of Thailand, (SET) 


\section{Introduction}

World economic development has environmental impacts that result in global warming, natural disasters and pollution. Therefore, many corporations take as much responsibility for environmental issues as they do for economic issues. One reason for this is that corporations are reflecting growing social expectations and stakeholder concerns. This notion of corporate social and environmental responsibility reflects both legitimacy and stakeholder theories. Responsibility is reflected in disclosures made by these companies: corporate social reporting. Henderson and Peirson (2004) explain that social and environmental reporting covers sustainability so that it reflects concerns about environmental protection, intergenerational equality, the Earth and its resources. There are reporting models that facilitate social and environmental disclosures such as triple bottom line reporting, the global reporting initiative and social and environmental management systems (O'Dwyer, 2002).

There has been a significant increase in the number of companies in both developed and developing countries making environmental disclosures in their annual reports and other communication media in the last two decades (C. M. Deegan \& Gordon, 1996; Kolk, 2003). After the 1989 oil spill in Alaska from the vessel, Exxon Valdez, firms in the petroleum industry and many firms in other environmentally sensitive industries dramatically increased and improved their disclosure of environmental information in annual or environmental reports (Z. Ahmad, Hassan, \& Mohammad, 2003; Anderson \& Epstein, 1995; Patten, 1992). Studies investigating why companies disclose environmental information in their annual or environmental reports have found that the reasons relate to demands by corporate stakeholders, pressure from regulations, the power of environmental groups, the influence of competitors and multinational companies, and improving corporate productivity and competitiveness.

Many studies of environmental disclosure in annual or environmental reports have focused on companies in developed countries such as the USA, the UK, Canada, Australia, New Zealand, Japan and the European Union (Kolk, Walhain, \& Wateringen, 2001) with few studies of environmental disclosure by companies in Thailand, a country heavily dependent on its environment for its economic well-being. In the case of Thailand, a developing country, little is known about the quantity of environmental information in corporate annual reports, nor the factors influencing environmental disclosures.

This study investigated the narrative disclosures of environmental information in the annual reports of listed companies on the Stock Exchange of Thailand (SET) and whether there are positive associations between the amount of environmental disclosure and various factors investigated in previous research. There were two main questions in the study: what is the extent and content of environmental information disclosure in Thai corporate annual reports, and what are the factors influencing those environmental disclosures? This study contributes to the literature relating to corporate disclosure by providing some empirical evidence for researchers, students, and academics with regard to the extent and content of environmental disclosure in Thailand and extends the knowledge derived from previous studies in developing countries, especially Thailand. The results of this study may encourage the Thai government to make corporate environmental reporting mandatory in the future.

This paper first examines corporate environmental disclosure from a theoretical perspective 
and then presents the background of environmental disclosure in Thailand. Next, the literature is reviewed before considering the characteristics influencing environmental reporting. The study's design and methodology are outlined and thereafter the findings are described, followed by its conclusions and limitations as well as recommendations for further studies.

\section{Theoretical perspective}

A number of different theoretical approaches have been used to explain corporate environmental disclosure. Some scholars have used political economy theory to explain the existence and content of environmental accounting (Williams, 1999) as well as social political theory (Huang \& Kung, 2010). Some have used media agenda setting theory to investigate the influence of the media on corporate environmental disclosure (Brown \& Deegan, 1998). However, the most complete theoretical perspective offered in the environmental accounting literature of corporate motivations for reporting employ legitimacy theory and stakeholder theory.

According to Gray et al. (1996) legitimacy theory and stakeholder theory are both derived from political economy theory. On one hand, legitimacy theory has become one of the most cited theories within the corporate environmental reporting area (Guthrie \& Parker, 1990). It offers many researchers a methodology to critically unpack corporate disclosures (N. N. N. Ahmad \& Sulaiman, 2004; Branco, Eugenio, \& Ribeiro, 2008; Campbell, 2003; Craig Deegan \& Rankin, 1996; M. Islam \& Deegan, 2010; Mobus, 2005; Wilmshurst \& Frost, 2000). On the other hand, stakeholder theory is closely aligned with legitimacy theory and the two theories are often used to complement each other (C. Deegan, 2002). Stakeholder theory is concerned with the ways companies manage their stakeholders (Gray, Collison, \& Bebbington, 1998; Llena, Monera, \& Hernandez, 2007; Roberts, 1992).

However, as Joshi and Gao (2009) and Huang and Kung (2010) note, disclosure is a complex phenomenon which cannot be explained by a single theory. Thus, some researchers have used a multi-theoretical framework in order to explain the extent and content of environmental disclosure (Choi, 1999; M. A. Islam \& Deegan, 2007; Ratanajongkol, Davey, \& Low, 2006; Tagesson, Blank, Broberg, \& Collin, 2009).

However, in this paper, only the influence of one theory will be considered, legitimacy theory which can be classified as a system-oriented theory that views companies as being part of a broader social system (C. Deegan, 2001). Within a system-based perspective, Deegan (2001) argues that companies are influenced by the society in which they operate. This means that environmental disclosures are considered to constitute a strategy to influence corporate relationships with other parties with which they interact.

\section{Legitimacy theory}

Legitimacy is a condition or status which exists when a corporate value system is congruent with the value system of the larger social system of which the company is a part (Lindblom, 1994). When a disparity, actual or potential, exists between the two value systems, there is a 


\section{Ml Macrothink}

International Journal of Accounting and Financial Reporting

ISSN 2162-3082

2012, Vol. 2, No. 1

threat to corporate legitimacy (Lindblom, 1994). Legitimacy theory proposes a relationship between corporate social disclosure and community concerns so that management must react to community expectations and changes (C. Deegan, 2001, 2002). Organizations seek to operate within the bounds and norms of their respective societies so they try to ensure that their activities are perceived as legitimate by outside parties because a corporation is part of a broader social system (C. Deegan, 2002). When there is a change in social expectations or stakeholders' concerns, corporations seek to ensure that their activities in terms of human, environmental, and other social consequences respond to those changes to meet social expectations (C. Deegan, 2001). If companies do not operate in a manner consistent with community expectations, they will be penalised so to be successful, corporations must adapt their activities to meet community expectations.

Legitimacy theory has been used in studies of social and environmental reporting practices. Many researchers have suggested that corporations legitimise their activities because corporate management reacts to community expectations (Guthrie \& Parker, 1990; Hogner, 1982; Patten, 1992; Tilt, 1994). Deegan et al. (1996) postulated that corporate social and environmental responsibility disclosure practices are responsive to environmental pressures on the basis of legitimacy theory. Campbell et al. (2003) argued that legitimacy theory explained how social and environmental disclosure can be used to narrow or close the gap between company actions and social concerns. Firms must seek a relationship between outside perceptions of their social concerns and their activities or actions serving corporate needs (C. Deegan, Rankin, \& Voght, 2000; Hogner, 1982). Legitimacy theory places stress on how corporate management reacts to community expectations (Guthrie \& Parker, 1990; Patten, 1992; Tilt, 1994) and annual or environmental reports are a means of reinforcing corporate responsibility for environmental situations (Craig Deegan \& Rankin, 1996; Patten, 1992).

Legitimacy theory has been used to analyse the various strategies management may choose to remain legitimate (C. Deegan, et al., 2000; Patten, 1992). Others link legitimacy theory to corporate social responsibility (CSR) and the increasing use of triple bottom line reporting (Elkington, 1997) and related notions of sustainability reporting. O'Donovan (1999) stated that legitimacy theory could explain why companies report environmental disclosures. Companies believe that they must act for society with socially acceptable behaviour that can enhance their business success. Many studies (C. Deegan, 2002; Hogner, 1982; O'Donovan, 2002; Wilmshurst \& Frost, 2000) have identified types of corporate social responsibility disclosure that have appeared in annual reports and which have been explained by the respective researchers as being part of the portfolio of strategies undertaken by accountants and managers to bring legitimacy to their respective corporations.

\section{Background}

In the early twentieth century, Thailand changed from an agricultural, self-sufficient economy into an industrialising nation. Its government has promoted Thailand as one of the rapidly industrialising nations of Asia (Kuasirikun, 2005). Thailand faced a financial crisis in mid of 1997 during which many domestic companies had to close their businesses, many workers 


\section{MInstitute Macrothink $_{\text {Int }}$}

International Journal of Accounting and Financial Reporting ISSN 2162-3082 2012, Vol. 2, No. 1

were unemployed and the Thai government did not have enough money to manage the country. Since then, the Thai economy has grown at about seven percentage per year (NESDB, 2003) making it one of fastest growing economies in South and South East Asia. Mukhopadbhay (2006) indicated that this high economic growth rate was led by growth in the manufacturing sector. However, Warr (2007) noted that this long term high economic growth created environmental problems, particularly air, noise, traffic and water pollution, deforestation and land erosion. Evidence that Thailand was suffering an environmental crisis was apparent as early as 1989 (Komin). Phongpaichit and Baker (1998) suggested that economic and industrial development from new industrial towns have caused so much pollution that Thailand faces an environmental crisis in many areas. Techamontrikul (1997) stated that the number of industries in Thailand have been increasing every year resulting from a pro-growth investment incentive policy but, unfortunately, these industries have created pollution problems.

As a result, the Thai government and the SET have been active in setting new rules and standards covering environmental disclosure (Connelly \& Limpaphayom, 2004). These rules and standards incorporate environmental accounting standards and an annual systematic evaluation of corporate governance practices. In 1999, Thai listed companies were asked by the SET to promote and build corporate governance practices into their annual reports (Ratanajongkol, et al., 2006). The concept of corporate governance included social and environmental disclosure in corporate annual reports, but disclosure was voluntary so not many listed companies in Thailand revealed social and environmental information in their annual reports. However, a revised version of the principles of good corporate governance was published in 2006 (Lint, 2009). The new principles suggested that the board of directors should set clear policies on social and environmental issues, and companies should disclose social and environmental policies as well as the implementation conditions of those policies. In addition, voluntary reporting was changed to a "comply or explain" approach. This new principle has been in operation for Thai listed companies since 2007. However, Thailand does not have any regulation requiring corporate environmental reporting.

\section{Literature review}

Only five papers were traced examining environmental disclosure by companies listed on the SET. William (1999) analysing 28 corporate annual reports, found that culture and the political and civil system were determinants of the quantity of disclosure. Kuasirikun and Sherer (2004) investigated corporate environmental disclosures in the annual reports of 63 Thai firms in 1993 and 84 firms in 1999, finding a slight increase in narrative disclosures from $44 \%$ to $45 \%$. Using a sample of the annual reports of 120 Thai listed companies to test the relationships between environmental reporting, market valuation and corporate accounting performance, Connelly and Limpaphayon (2004) found that there was a significant positive correlation between market valuation and disclosure but there was no such relationship between environmental reporting and Thai corporate accounting performance. Ratanajongkol et al. (2006) examined trends in corporate environmental disclosure by analysing the content of the disclosures made by the 40 largest Thai firms in 
1997, 1999, and 2001, finding that the number of environmental disclosures decreased over the study period. Rahman et al. (2010) studied the 2006 annual reports of a sample of 37 Thai listed companies to investigate if there was a relationship between environmental disclosure and financial performance but found that no such relationship existed.

However, none of the above studies of Thai companies explored what factors influence the amount of environmental disclosure, and there has been no recent investigation of the information available regarding the extent and content of disclosures in Thailand. Therefore, there are two main questions in this study: what is the extent and content of environmental information disclosures in Thai corporate annual reports, and what are the factors influencing those environmental disclosures?

\section{Characteristics influencing environmental disclosures}

In answering the research questions, the data collection was based on a number of company characteristics used in previous studies, thus allowing for comparisons to be made with those studies. The study examines the influence of the following commonly cited characteristics: company size, industry type, ownership status, country of origin, and profitability. Each is examined in turn and hypotheses as to their relationship to the amount of environmental disclosure proposed.

\subsection{Size of company}

Legitimacy theory suggests that larger companies have to respond with more disclosures to have a greater impact on social expectations because they have more stakeholders than small companies (Cowen, Ferreri, \& Parker, 1987). Many previous studies (Choi, 1999; Cormier \& Gordon, 2001; C. M. Deegan \& Gordon, 1996; Ho \& Taylor, 2007; Raar, 2002; Stanwick \& Stanwick, 2006) found a positive association between amounts of environmental disclosure in corporate annual reports and the size of companies although (Davey, 1982; Ng, 1985; Roberts, 1992) did not find such a relationship. In this study, the hypothesis is that there is a positive relationship between the amount of environmental disclosure in annual reports and the size of the company

\subsection{Type of industry}

In many previous studies, companies were classified according to various criteria. Commonly companies are separated into two types; high or low profile companies (Choi, 1999; Hackston \& Milne, 1996; Patten, 1992). High profile companies are those operating in highly environmentally sensitive industries (Perry and Sheng 1999; Stray and Ballantain 2000; Ho and Taylor 2007), and are thus more exposed to the political and social environment than low profile companies (Newson \& Deegan, 2002). Using the relationship between the levels of corporate environmental disclosure in annual reports and type of industry, many studies $(\mathrm{N}$. N. N. Ahmad \& Sulaiman, 2004; Choi, 1999; Ho \& Taylor, 2007; Newson \& Deegan, 2002; 
Stray \& Ballantine, 2000) have found that companies in high environmentally sensitive industries disclose more environmental information in annual reports than companies in low profile industries. However an early study by Cowen et al. (1987) and a later one in India (Sahay, 2004) found no association between type of industry and the levels of corporate environmental disclosure. The hypothesis in this study is that there is a positive relationship between the amount of environmental disclosure in annual reports and companies in high profile industries.

\subsection{Ownership status}

This study also separates companies into two types of ownership status based on the percentage of corporate common stock held by either government or private companies. In particular, if government organizations own more than 51 percent of the common stock of companies, then these firms are called government companies. On the other hand, if private organizations or individuals hold more than 51 percent of the common stock, these are classified as private companies. Actually, ownership status is not very often considered in research into environmental reporting, probably because such research is mostly conducted in an Anglo-American context where government companies are not common (Tagesson, et al., 2009).

In relation to environmental information, government and private companies may differ in both the quantity and quality of their disclosures. In Canada, Cormier and Gordon (2001) found that government companies provide more environmental information in corporate annual reports than private companies. In Sweden, Tagesson et al. (2009) found that government companies disclosed more environmental information than private companies because state-owned companies are under greater scrutiny, and there is pressure from the owner, the state, and from the mass media to comply with society's expectations. On the other hand, in Bangladesh, Balal (2000) found that private companies disclose more environmental information in annual reports than government companies. In Italy, Secci (2005) found that companies controlled by the Italian government disclosed less environmental information than other corporations. Because of expected differences in environmental disclosures of government and private companies, the hypothesis is that government companies will make more environmental disclosures in corporate annual reports than private companies.

\subsection{Country of origin of the company}

In a similarly way to the above categorisation, SET listed companies can be separated into two kinds: international and domestic companies. International companies are those founded in developed countries but located in Thailand, on the other hand, domestic companies are those both founded and located in Thailand. Previous studies suggest that companies from developed countries make more social and environmental information disclosures than companies in developing countries (Adams, Hill, \& Roberts, 1998; Kolk, et al., 2001). Possible associations between the country of origin of the company making the disclosures 


\section{$\Lambda$ Macrothink}

International Journal of Accounting and Financial Reporting ISSN 2162-3082 2012, Vol. 2, No. 1

and the amount of corporate social and environmental disclosure have been found by (Hackston \& Milne, 1996; Jahamani, 2003; Niskala \& Pretes, 1995; Stanwick \& Stanwick, 2006). However, this characteristic has never been tested in respect of the disclosures made by Thai listed companies. However, the hypothesis is that there is a positive relationship between the levels of environmental disclosures in annual reports and international companies.

\subsection{Profitability}

Previous studies have found different results in regard to the relationship between social and environmental disclosure and financial performance. Firstly, some studies have found that social and environmental reporting and financial performance are positively linked (Russo and Founts, 1997, Cohen et al, 1997). Cohen et al. (1997) stated that companies that make social and environmental disclosures may be those able to effectively reduce pollution as well as employing more efficient methods of production, and thereby gain competitive advantage. On the other hand, some previous studies found a negative relationship between social and environmental disclosure and financial performance (King and Lenox, 2001, Mathur and Mathur, 2000). Their results suggest that social and environmental disclosure entails costs to companies and acts to reduce corporate financial performance. Finally, no correlation between social and environmental disclosure and financial performance was found by Connelly and Limpaphayom (2004) or Stanwick and Stanwick (2000). However, the hypothesis in this study is that there is a positive relationship between the amount of environmental disclosure in annual reports and profitability.

\section{Study method}

This study investigated the extent and content of environmental disclosure in annual reports of companies listed on the SET, and tested whether there is any relationship between the amount of disclosure and a variety of factors. The population for the study was all the companies listed on the SET in 2007. Out of over 500 listed companies, 75 were selected for analysis by simple random sampling, with a requirement that appoximately 15 percent of the companies listed in each of the eight SET industry groups were selected so that the proportions of the sample selected from the eight groups reflected the overall proportions of companies from the eight different groups among the total population of SET listed companies.

The data needed for this study were collected from the annual reports of each of the companies sampled. The corporate annual reports were used to investigate environmental disclosure because firstly, they are statutory reports incorporating both statutory and voluntary disclosures. Secondly, they can be accessed more easily than can other media, and finally, they are widely recognised as the principal means for the communication of corporate activities and intentions (Wiseman, 1982). The Thai text versions of the annual reports were used to collect the data since Thai is the usual reporting language. This was not the first study to examine non-English reports; there have been two previous papers reporting studies which 


\section{Mll Macrothink}

International Journal of Accounting and Financial Reporting

ISSN 2162-3082

2012, Vol. 2, No. 1

looked at vernacular reports. Choi (1999) investigated environmental disclosures in Korean corporate semi-annual reports using the Korean text versions, and Balal (2000) used Bangladeshi language versions of reports to examine environmental disclosures in Bangladeshi corporate annual reports.

This study used content analysis by word count to quantify environmental disclosure in Thai corporate annual reports issued in 2007. Based on previous studies by Burritt (1982), Wiseman (1982), Deegan and Gordon (1996), and Hackston and Milne (1996), there are 22 themes that can be used to categorise environmental information in annual reports; they are:

1. Environmental policy including lists of environmental objectives, environmental issues of concern, and prioritisation of environmental issues in term of their impacts;

2. Environmental management systems including ISO14000 and responsible persons;

3. Risk management including environmental impact assessment;

4. Environmental audit;

5. Goals and targets including performance against targets, and actions taken;

6. Compliance with standards including benchmarks;

7. Awards;

8. Input including R\&D, energy management, and non- renewable resources used;

9. Processes including technology employed, and capital equipment;

10. Product stewardship including life cycle analysis, and eco-labelling;

11. Wastes consisting of recycling, reduction, and reuse;

12. Land rehabilitation and remediation;

13. Air emissions;

14. Water effluent;

15. Spills;

16. Noise and odours;

17. Environmental spending and activities;

18. Rehabilitation costs consisting of operating costs, provisions, and contingent liabilities;

19. Environmental cost accounting;

20. Sustainable development reporting including a statement that the company subscribes to the principle of sustainable development, details of the principle, attempts to connect the environmental and economic dimensions, impact on the biosphere and habitat carrying capacity, natural trust account, eco-asset sheet, and natural capacity;

21. Education and training; and

22. Litigation about environmental issues.

The dependent variable, the amount of environmental disclosure in Thai corporate annual reports, was measured by word count. The independent variables in the study were the five characteristics set out above which were analysed to establish if any relationships existed with the dependent variable. The independent variables were measured as follows: Firstly, size of company was measured by the sales revenue of each company studied (Belkaoui \& Karpik, 1989; Hackston \& Milne, 1996), even though some previous studies have used the number of employees or total assets (Adams, et al., 1998; Roberts, 1992). As previously mentioned, companies were classified by type of industry based on whether the company fell 


\section{Ml Macrothink}

International Journal of Accounting and Financial Reporting

ISSN 2162-3082

2012, Vol. 2, No. 1

ino the classification of a high or low profile company (Choi, 1999; Hackston \& Milne, 1996; Patten, 1992) where 1 = high profile company and $2=$ low profile company. Thirdly, ownership status was measured by a dummy variable, where $1=$ government company and 2 = private company. Next, country of origin of company was also measured by a dummy variable, where $1=$ international company and $2=$ domestic company. Finally, profitability was measured by reported net profit.

\section{Findings}

Of the 75 Thai listed companies sampled, based on their 2007 annual reports, 62 firms $(82.67 \%)$ made environmental disclosures. They averaged 334 words of environmental information per annual report (see Table 1 which also indicates the categories of the disclosures and their location in the report as well as other forms of environmental disclosure). The most common location for disclosures was in sections devoted to corporate governance followed by CEO's reports, and sections headed, environmental effect, and corporate social responsibility. In relation to other forms of environmental disclosures, photographs were the form most commonly used to reveal environmental information in annual reports.

Table 1: The extent of environmental disclosure in annual reports

\begin{tabular}{lll}
\hline Topics & No. of company & Percentage \\
\hline $\begin{array}{l}\text { Number of companies making environmental } \\
\text { disclosures in annual reports }\end{array}$ & 62 & 82.67 \\
\hline Other forms of environmental disclosures & & \\
$\quad$ Photograph & 16 & 21.3 \\
Chart & 2 & 2.7 \\
Table & 2 & 2.7 \\
Graph & 1 & 1.3 \\
\hline Locations of environmental disclosures & & \\
Corporate governance & 45 & 65.3 \\
CEO report & 14 & 18.7 \\
Environmental effect & 13 & 17.3 \\
Corporate social responsibility & 12 & 16.0 \\
Environmental activity & 11 & 14.7 \\
Vision and mission & 9 & 12.0 \\
Environmental policy & 6 & 8.0 \\
Operation & 5 & 6.7 \\
Risk management & 5 & 6.7 \\
Awards & 4 & 5.3 \\
\hline
\end{tabular}

The themes of the environmental disclosures made in Thai corporate annual reports are itemized in Table 2 based on the mean word count devoted to each category of disclosure. The most common themes of environmental disclosure in annual reports were on the topics of environmental policy, environmental spending and activities, waste management, water 


\section{Ml Macrothink}

International Journal of Accounting and Financial Reporting

ISSN 2162-3082

2012, Vol. 2, No. 1

effluent, and environmental management systems (ISO14001). On the other hand, land rehabilitation, environmental accounting, and litigation were the least common themes of disclosures.

Table 2: Themes of environmental disclosures in annual reports

\begin{tabular}{llll}
\hline No. & Theme & Mean (Word) & S.D. \\
\hline 1 & Environmental policy & 64.24 & 103.30 \\
2 & Environmental spending and activities & 55.89 & 105.80 \\
3 & Waste management & 43.53 & 98.40 \\
4 & Water effluent & 33.80 & 101.54 \\
5 & Environmental management systems - ISO14001 & 25.23 & 66.25 \\
\hline 6 & Input & 20.59 & 55.01 \\
7 & Air emissions & 17.28 & 71.38 \\
8 & Standards & 17.12 & 31.99 \\
9 & Risk management & 16.31 & 60.58 \\
10 & Awards & 13.35 & 45.57 \\
\hline 11 & Education and training & 6.28 & 17.73 \\
12 & Goals and targets & 3.89 & 16.55 \\
13 & Environmental audit & 3.19 & 19.22 \\
14 & Noise and odours & 2.91 & 12.15 \\
15 & Spills & 2.81 & 17.31 \\
\hline 16 & Process & 2.44 & 13.41 \\
17 & Rehabilitation costs & 1.56 & 11.31 \\
18 & Output & 1.17 & 5.79 \\
19 & Sustainable development & 1.04 & 6.36 \\
20 & Litigation & 0.55 & 3.45 \\
\hline 21 & Environmental accounting & 0.00 & 0.000 \\
22 & Land rehabilitation and remediation & 0.00 & 0.000 \\
\hline The amount of environmental disclosures (Total) & 333.89 & 475.198 \\
\hline & & & \\
\hline
\end{tabular}

In Table 3 below, the companies have been separated into eight groups based on the nature of the industry as categorized by the SET. As can be seen, the results show that the companies disclosing the most environmental information were those in the resources group, followed by those in the consumer products group, and the industrial group, with companies in the agricultural and food, and service industries groups making the least disclosures. Further, there were only two industry groups where environmental information was provided by all the companies sampled in that group, the industrial and technology groups.

Table 3: Environmental reporting by each industry group 


\begin{tabular}{lll}
\hline Industry & Mean (Word) & S.D. \\
\hline Agricultural and food & 126.33 & 130.752 \\
\hline Consumer products & 535.13 & 427.424 \\
\hline Financial & 366.83 & 461.869 \\
\hline Industrials & 448.50 & 713.163 \\
\hline Property and construction & 284.77 & 479.688 \\
\hline Resources & 656.50 & 928.431 \\
\hline Services & 240.50 & 408.815 \\
\hline Technology & 291.60 & 275.665 \\
\hline Total & 333.89 & 475.198
\end{tabular}

To test the levels of association between the amount of environmental disclosure and the independent variables (size of company, type of industry, ownership status, country of origin of the company, and profitability), Pearson correlation coefficients were derived between the dependent variable and the independent variables which are shown in Table 4 where the correlation coefficients are reported in the top of each cell, and the associated one-tailed $\mathrm{p}$ values appear below in each cell.

Table 4: Pearson correlation coefficients

\begin{tabular}{lllllll}
\hline & Disclosures & $\begin{array}{l}\text { Size of } \\
\text { company }\end{array}$ & $\begin{array}{l}\text { Type of } \\
\text { industry }\end{array}$ & $\begin{array}{l}\text { Ownership } \\
\text { status }\end{array}$ & $\begin{array}{l}\text { Country of } \\
\text { origin }\end{array}$ & Profitability \\
\hline Disclosures & 1.000 & 0.451 & 0.065 & -0.250 & 0.053 & 0.099 \\
Sig(1tailed) & & $0.000^{* *}$ & 0.289 & $0.015^{* *}$ & 0.327 & 0.200 \\
\hline Size & 1.000 & 0.064 & -0.396 & -0.117 & 0.183 \\
Sig(1tailed) & & 0.294 & $0.000^{* *}$ & 0.158 & 0.058 \\
\hline Type & & 1.000 & -0.065 & -0.131 & -0.061 \\
Sig(1tailed) & & & 0.289 & 0.132 & 0.303 \\
\hline Ownership & & & 1.000 & -0.098 & -0.085 \\
Sig(1tailed) & & & & 0.202 & 0.234 \\
\hline Country & & & & 1.000 & 0.302 \\
Sig(1tailed) & & & & & $0.004^{* *}$ \\
\hline Profitability & & & & & \\
Sig(1tailed) & & & & & \\
\hline$* *$ Significant at the 0.01 level & & & & &
\end{tabular}

From Table 4, it is clear that the size of company (measured by sales) was moderately positively correlated with the amount of environmental disclosure in Thai corporate annual reports. The ownership status was slightly negatively correlated with the amounts of environmental disclosures. However, none of the other factors, type of industry, country of origin of the company, and profitability were significantly associated with environmental disclosures.

To examine whether there was any predictive relationship between any of the independent variables and the amount of environmental disclosure, multiple regression was used based on the following formula: 
Environmental disclosure $=a_{1}+b_{1}$ Size $+b_{2}$ Industry $+b_{3}$ Owner

$$
+b_{4} \text { Country }+b_{5} \text { Profit }
$$

Environmental disclosures $=$ amount of disclosure measured by word count

$\begin{array}{ll}\text { Size } & =\quad \begin{array}{l}\text { size of company is measures by sales } \\ \text { Industry }=\end{array} \\ \text { Owner } & =\begin{array}{l}1=\text { high profile, } 2=\text { low profile } \\ \text { ownership status, dummy variable with } \\ \text { Country }=\end{array} \\ \text { Profit } \quad=\quad \begin{array}{l}\text { government, } 2=\text { private } \\ \text { with } 1=\text { international, } 2=\text { domestic } \\ \text { profitability as measured by net profit }\end{array}\end{array}$

The results of the multiple regression are shown in Table 5. These findings show that only the size of company had a significant relationship with the amount of environmental disclosure $(\mathrm{p}<0.001)$, while type of company, ownership status, the country of origin of the company and profitability had no significant relationship with disclosure.

Table 5: Multiple regression

\begin{tabular}{llllll}
\hline \multicolumn{7}{l}{ Disclosure $=\mathrm{a}_{1}+\mathrm{b}_{1}$ Size $+\mathrm{b}_{2}$ Industry $+\mathrm{b}_{3}$ Owner $+\mathrm{b}_{4}$ Country $+\mathrm{b}_{5}$ Profit } \\
\hline & $\mathrm{B}$ & Std. Error & Beta & $\mathrm{T}$ & $\mathrm{Sig}$ \\
\hline (Constant) & 216.355 & 695.220 & & 0.311 & 0.757 \\
\hline SIZE & $1.281 \mathrm{E}-8$ & 0.000 & 0.439 & 3.643 & $0.001^{* *}$ \\
\hline TYPE & 43.770 & 101.552 & 0.046 & 0.431 & 0.668 \\
\hline OWNER & -152.470 & 283.102 & -0.063 & -0.539 & 0.592 \\
\hline COUNTRY & 132.361 & 140.151 & 0.109 & 0.944 & 0.348 \\
\hline PROFIT & $-1.379 \mathrm{E}-9$ & 0.000 & -0.018 & -0.153 & 0.879 \\
\hline$* *$ Significant at the 0.01 level & & & &
\end{tabular}

\section{Conclusions}

This study investigated the extent and content of environmental information disclosure provided in the annual reports of Thai listed companies, and tested whether there was any relationship between the amount of environmental disclosure and a variety of factors. The initial findings indicate that 82.67 percent of the Thai listed companies sampled made environmental disclosures in their annual reports. The companies making the most environmental disclosure were in the resource industry group with the lowest disclosure being made by companies in the agricultural and food industries group. The most common location for disclosures in annual reports was in sections devoted to corporate governance (CG). The most common themes of environmental disclosure were environmental policy, environmental spending and activities, and waste management. Finally, there was a positive relationship between the amount of environmental disclosure in Thai corporate annual reports and the size of the companies making the disclosures.

This study therefore supports legitimacy theory because the results indicate that larger 
companies with more community concerns make more environmental disclosure than smaller companies. This study provides some empirical evidence for researchers, students, and academics of the extent and content of environmental disclosure in Thailand and extends the findings of previous studies in developing countries, especially Thailand. The results of this study might also encourage the Thai government to make corporate environmental reporting mandatory in the future.

However, in pointing out the contribution that the study makes to the corporate disclosure literature, it is important to acknowledge some key limitations, in particular, the sole use of annual reports as the tool through which the study's data was collected, the subjectivity of the data collection methods used, and the time period of the study. It is recommended that further studies should be undertaken to explore the environmental disclosures of Thai listed companies in other communication media such as corporate web sites and stand-alone environmental reports. Further efforts should be made to establish from company management the reasons that companies provide environmental information in their annual reports. Moreover, the trend of environmental disclosure in annual reports should be studied by using longitudinal data.

\section{References}

Adams, C., Hill, W.-Y., \& Roberts, C. (1998). Corporate social reporting practices in Western Europe: legitimating corporate behaviour? British Accounting Review, 30(1), 1-21.

Ahmad, N. N. N., \& Sulaiman, M. (2004). Environmental disclosures in Malaysian annual reports: a legitimacy theory perspective. IJCM, 14(1), 44-58.

Ahmad, Z., Hassan, S., \& Mohammad, J. (2003). Determinants of environmental reporting in Malaysia. International Journal of Business Studies, 11(1), 69-90.

Anderson, R. H., \& Epstein, M. (1995). The usefulness of annual reports. Australian Accountant, April, 25.

Balal, A. R. (2000). Environmental reporting in developing countries: empirical evidence from Bangladesh. Eco - Management and Auditing, 7(3), 114-121.

Belkaoui, B. H., \& Karpik, P. G. (1989). Determinants of the corporate decision to disclose social information. Accounting, Auditing \& Accountability Journal, 2(1), 36-51.

Branco, M. C., Eugenio, T., \& Ribeiro, J. (2008). Environmental disclosure in response to public perception of environmental threats: the case of co-incineration in Portugal. Journal of Communication Management, 12(2), 136-151.

Brown, N., \& Deegan, C. (1998). The public disclosure of environmental performance information- a dual test of media agenda setting theory and legitimacy theory. Accounting and Business Research, 29(1), 21-41.

Campbell, D. (2003). Intra- and intersectional effects in environmental disclosures: evidence for legitimacy theory? Business Strategy and the Environment, 12(6), 357-371.

Campbell, D., Craven, B., \& Shrives, P. (2003). Voluntary social reporting in three FTSE sectors: A comment on perception and legitimacy. Accounting, Auditing \& Accountability Journal, 16(4), 558-581.

Choi, J.-S. (1999). An investigation of the initial voluntary environmental disclosures made in 
Korean semi-annual financial reports. Pacific Accounting Review, 11(1), 73-102.

Connelly, J. T., \& Limpaphayom, P. (2004). Environmental reporting and firm performance: evidence from Thailand. The Journal of Corporate Citizenship, 13, 137-149.

Cormier, D., \& Gordon, I. M. (2001). An examination of social and environmental reporting strategies. Accounting, Auditing \& Accountability Journal, 14(5), 587-616.

Cowen, S. S., Ferreri, L. B., \& Parker, L. D. (1987). The impact of corporate characteristics on social responsibility disclosure: a typology and frequency-based analysis. Accounting, Organizations and Society, 12(2), 111-122.

Davey, H. B. (1982). Corporate social responsibility dsiclosure in New Zealand: an empirical investigation, unpublished working paper Massey University, Palmerton North.

Deegan, C. (2001). Financial Accounting Theory. Roseville, NSW: McGraw-Hill Book Company Australia Pty Limited.

Deegan, C. (2002). Introduction: the legitimising effect of social and environmental disclosures- a theoretical foundation. Accounting, Auditing \& Accountability Journal, 15(3), 282-311.

Deegan, C., \& Rankin, M. (1996). Do Australian companies report environmental news objectively? An analysis of environmental disclosures by firms prosecuted successfully by the Environmental Protection Authority. Accounting, Auditing \& Accountability Journal, 9(2), 52-69.

Deegan, C., Rankin, M., \& Voght, P. (2000). Firms' disclosure reactions to major social incidents: Australian evidence. Accounting Forum, 24(1), 101-130.

Deegan, C. M., \& Gordon, B. (1996). A study of the environmental disclosure practices of Australian corporations. Accounting and Business Research, 26(3), 187-199.

Gray, R., Collison, D., \& Bebbington, J. (1998). Environmental and social accounting and reporting. London: ICAEW.

Gray, R., Owen, D., \& Adams, C. (1996). Accounting and Accountability: Changes and Challenges in Corporate and Social Reporting. London: Prentice Hall.

Guthrie, J., \& Parker, L. (1990). Corporate social disclosure practice: a comparative international analysis. Advances in Public Interest Accounting, 3, 159-176.

Hackston, D., \& Milne, M. J. (1996). Some determinants of social and environmental disclosures in New Zealand companies. Accounting, Auditing \& Accountability Journal, 9(1), 77-108.

Henderson, S., \& Peirson, G. (2004). Issues in Financial Accounting. Frenchs Forest, NSW: Pearson Education Australia.

Ho, L. J., \& Taylor, M. E. (2007). An empirical analysis of triple bottom-line reporting and its determinates: evidence from the United States and Japan. Journal of International Financial Management and Accounting, 18(2), 123-150.

Hogner, R. H. (1982). Corporate social reporting: eight decades of development at US steel. Research in Corporate Social Performance and Policy, 4, 243-250.

Huang, C. L., \& Kung, F. H. (2010). Drivers of environmental disclosure and stakeholder expectation: evidence from Taiwan. Journal of Business Ethics, 96, 435-451.

Islam, M., \& Deegan, C. (2010). Media pressures and corporate disclosure of social responsibility performance information: a study of two global clothing and sports retail 
companies. Accounting and Business Research, 40(2), 131-148.

Islam, M. A., \& Deegan, C. (2007). Motivations for an organisation within a developing country to report social responsibility information: evidence from Bangladesh. Accounting, Auditing \& Accountability Journal, 21(6), 850-874.

Jahamani, Y. F. (2003). Green accounting in developing countries: the case of U.A.E. and Jordan. Managerial Finance, 29(8), 37-45.

Joshi, P. L., \& Gao, S. S. (2009). Multinational corporate social and environmental disclosures (CSED) on web sites. International Journal of Commerce \& Management, 19(1), 27-44.

Kolk, A. (2003). Trends in sustainability reporting by the furtune global 250. Business Strategy and the Environment, 12, 279-291.

Kolk, A., Walhain, S., \& Wateringen, S. (2001). Environmental reporting by the Fortune Global 250: exploring the influence of nationality and sector. Business Strategy and the Environment, 10(1), 15-28.

Kuasirikun, N. (2005). Attitudes to the development and implementation of social and environmental accounting in Thailand. Critical Perspectives on Accounting, 16(8), 1035-1057.

Kuasirikun, N., \& Sherer, M. (2004). Corporate social accounting disclosure in Thailand. Accounting, Auditing \& Accountability Journal, 17(4), 629-660.

Lindblom, C. (1994). The implications of organizational legitimacy for corporate social performance and disclosure. Paper presented at the Critical Perspectives on Accounting Conference New York.

Lint, L. W. (2009). Corporate social and environmental disclosure in energing securities markets. North Carolina Journal of International Law and Commercial Regulation, 35(1), $1-32$.

Llena, F., Monera, J. M., \& Hernandez, B. (2007). Environmental disclosure and compulsory accounting standards: the case of Spanish annual reports. Business Strategy and the Environment, 16, 50-63.

Mobus, J. L. (2005). Mandatory environmental disclosures in a legitimacy theory context. Accounting, Auditing \& Accountability Journal, 18(4), $492-517$.

Mukhopadbhyay, K. (2006). Impact on the environment of Thailand's trade with OECD countries. Asia-Pacific Trade and Investment Review, 2(1), 25-46.

NESDB. (2003). National income of Thailand, 1980-2001. Bangkok: Office of the Prime Minister.

Newson, M., \& Deegan, C. (2002). Global expectations and their association with corporate social disclosure practices in Australia, Singapore, and South Korea. The International Journal of Accounting, 37, 183-213.

Ng, L. W. (1985). Social responsibility disclosures of selected New Zealand companies for 1981, 1982, and1983, Occasional paper No.54. Massey University, Palmerton North.

Niskala, M., \& Pretes, M. (1995). Environmental reporting in Finland: a note on the use of annual reports. Accounting, Organizations and Society, 20(6), 457-466.

O'Donovan, G. (1999). Managing legitimacy through increased corporate reporting: an exploratory study. interdisciplinary environmental Review, 1(1), 63-99. 
O'Donovan, G. (2002). Environmental disclosures in the annual report: Extending the applicability and predictive power of legitimacy theory. Accounting, Auditing \& Accountability Journal, 15(3), 344-372.

O'Dwyer, B. (2002). Managerial perceptions of corporate social disclosure: an Irish story. Accounting, Auditing \& Accountability Journal, 15(3), 406-436.

Patten, D. (1992). Intra-industry environmental disclosures in response to the Alaskan oil spill: a note on legitimacy theory. Accounting, Organizations and Society, 17(5), 471-475.

Phongpaichit, P., \& Baker, C. (1998). Thailand's boom and bust Silkworm Books. Chaing-Mai.

Raar, J. (2002). Environmental initiatives: towards triple-bottom line reporting. Corporate Communications, 7(3), 169-183.

Rahman, S. A. B. A., Yusoff, R. B., \& Mohamed, W. N. B. W. (2010). Environmental disclosures and financial performance: an empirical study of Malaysia, Thailand, and Singapore. 22 November 2010, 29(2), 46-58

Ratanajongkol, S., Davey, H., \& Low, M. (2006). Corporate social reporting in Thailand, the news is all good and increasing. Qualitative Research in Accounting \& Management, 3(1), 67-83.

Roberts, R. (1992). Determinants of corporate social responsibility disclosure: an application of stakeholder theory Accounting, Organizations and Society 17(6), 595-612.

Sahay, A. (2004). Environmental reporting by Indian corporations. Corporate Social Responsibility and Environmental Management, 11, 12-22.

Secci, D. (2005). The Italian experience in social reporting: an empirical analysis. Corporate Social Responsibility and Environmental Management, 13, 135-149.

Stanwick, P., \& Stanwick, S. (2006). Corporate environmental disclosure: a longitudinal study of Japanese firms. Journal of American Academy of Business, 9(1), 1-7.

Stray, S., \& Ballantine, J. (2000). A sectoral comparison of corporate environmental reporting and disclosure. Eco - Management and Auditing, 7(4), 165-177.

Tagesson, T., Blank, V., Broberg, P., \& Collin, S. O. (2009). What explains the extent and content of social and environmental reporting in Swedish listed corporations. Corporate Social Responsibility and Environmental Management, 16, 352-364.

Techamontrikul, S. (1997). Environmental disclosures for companies listed in the stock exchange of Thailand: guidelines and model. Chulalongkorn University, Bangkok.

Tilt, C. A. (1994). The influence of external pressure groups on corporate social disclosure. Accounting, Auditing \& Accountability Journal, 7(4), 56-71.

Warr, P. (2007). Long-term economic performance in Thailand. ASEAN Economic Bulletin, 24(1), 138-163.

Williams, S. M. (1999). Voluntary environmental and social accounting disclosure practice in the Asia-Pacific region: an international empirical test of political economy theory. The International Journal of Accounting, 34(2), 209-238.

Wilmshurst, T. D., \& Frost, G. R. (2000). Corporate environmental reporting: a test of legitimacy theory. Accounting, Auditing \& Accountability Journal, 13(1), 10-25.

Wiseman, J. (1982). An evaluation of environmental disclosures made in corporate annual reports. Accounting, Organizations and Society, 4(1), 123-133. 